\title{
Regulating Flexibility and Small Business: Revisiting the LRA and BCEA A Response to Halton Cheadle's Concept Paper
}

\author{
André van Niekerk \\ Perrott, Van Niekerk \& Woodhouse Inc. \\ Sandton \\ vanniekerk@elaw.co.za
}

Development Policy Research Unit

DPRU Working Paper 07/119

ISBN: 978-1-920055-41-7

March 2007 


\section{Abstract}

This paper is a response, from a business perspective, to Halton Cheadle's concept paper titled 'Regulating flexibility: Revisiting the LRA and the BCEA' (DPRU Working Paper 06/109).

This paper seeks to respond to each of the issues raised by Cheadle, and to his reflections on each. As previously noted, the paper has been drafted to present a business perspective. This brief presents its own difficulties. The business community in South Africa is a broad church, and encompasses manifold shades of opinion on the appropriate nature and extent of labour market regulation.

Organised business, represented by national employer organisations, professional organisations and chambers of commerce, has been a party to the negotiations preceding the enactment of the legislation under review. In this sense, organised business is also a party to the broad agreements reached by the social partners on the conceptual underpinnings of the legislative reforms introduced in 1995. However, business is equally cognisant that the concept of regulated flexibility, as Cheadle observes, inherently recognises the diverse and dynamic nature of the labour market, and requires that regulatory frameworks should be capable of adaptation to meet the demands of changing circumstances.

What this paper attempts primarily is a review of the existing legislative and regulatory package, questioning where necessary the appropriateness of the continued application of the limits and mechanisms that are intended to promote regulated flexibility, and reviewing the balance that the existing legislation seeks to achieve.

The paper does not purport to present the mandated views of organised business or any other component of the business constituency, rather than to raise for discussion general and specific issues that might be relevant to the debate initiated by Cheadle's paper. 


\section{Acknowledgement}

This Working Paper is one in a series emanating from the SMME project, within the Employment Promotion Programme, which is aimed at Understanding the Regulatory Environment for Small Business in South Africa. The DPRU are the Programme Managers of this DFID funded project whose goal is to promote an enabling environment for employment creation in South Africa, and to contribute to the Government's goal of reducing unemployment.

Development Policy Research Unit Tel: +2721650 5705

Fax: +27 216505711
Information about our Working Papers and other published titles are available on our website at: http://www.commerce.uct.ac.za/dpru/ 


\section{Table of Contents}

1. Purpose and Structure of the Paper.................................

2. South African Labour Laws: An Overview and Perspective.....................................................................4

2.1 Perspectives and Constraints.............................................4

2.2 How Inflexible is South African Labour Legislation?..............7

3. Refining the Balance: A Review of the LRA and BCEA............................................................................12

3.1 Introduction..................................................................12

3.2.1 Protection of Work Security - Unfair Dismissal Laws.........13

3.2 The Individual Employment Relationship.....................................13

a. The Scope of Application of Unfair Dismissal Laws....................14

b. Senior Managerial Employees.....................................................15

c. Fair Reason for Dismissal: Incapacity: Probation.........................16

d. Fair Procedure......................................................................18

e. Dismissal for Operational Requirements.................................24

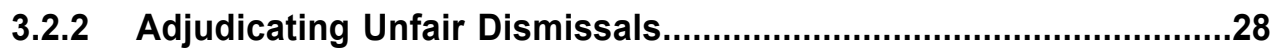

3.2.3 The Unfair Labour Practice.........................................................30

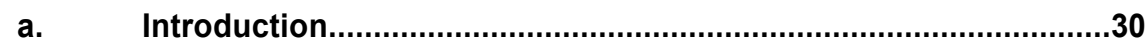

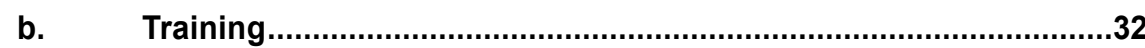

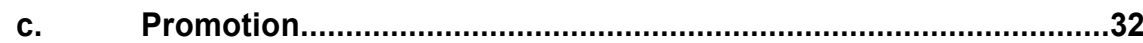

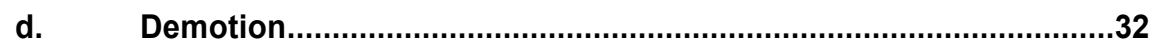

e. Discipline short of dismissal....................................................33

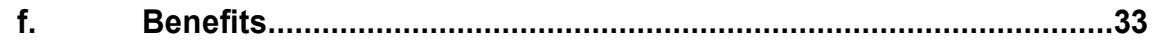

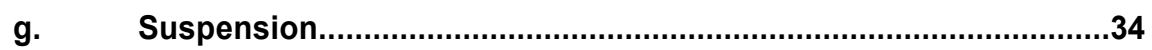

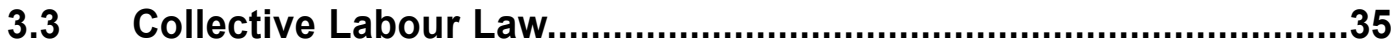

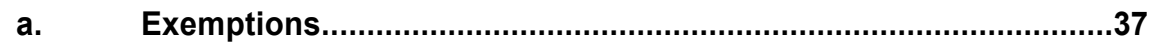

b. Basic Conditions of Employment Act..........................................37

3.4 Labour Market Institutions...........................................................38

3.4.1 The Labour Courts........................................................................38

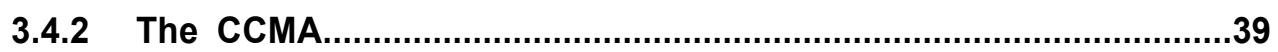

4. Conclusions...................................................................43

5. $\quad$ References.................................................................48 


\section{Purpose and Structure of the Paper}

This paper is a response, from a business perspective, to Halton Cheadle's concept paper titled 'Regulating flexibility: Revisiting the LRA and the BCEA' (DPRU Working Paper 06/109).

Cheadle's paper reflects on three issues - the conceptual underpinnings of the labour law reforms initiated in 1994, those aspects of the reforms that were improperly realised in practice, and whether the existing conceptual structure is capable of accommodating changes in the labour market that have occurred in the last ten years.

Cheadle concludes that the concept of regulated flexibility, the primary conceptual underpinning of the labour law reforms initiated in 1994, may be put to good use in extending protection to those who need it, and limiting judicial intervention where there is no appreciable gain in protection or where other mechanisms are capable of providing adequate protection. This conclusion is the benchmark against which Cheadle scrutinises and measures current labour legislation, and the basis for the adjustments to the current legislation that he proposes.

This paper seeks to respond to each of the issues raised by Cheadle, and to his reflections on each. As previously noted, the paper has been drafted to present a business perspective. This brief presents its own difficulties. The business community in South Africa is a broad church, and encompasses manifold shades of opinion on the appropriate nature and extent of labour market regulation.

Organised business, represented by national employer organisations, professional organisations and chambers of commerce, has been a party to the negotiations preceding the enactment of the legislation under review. In this sense, organised business is also a party to the broad agreements reached by the social partners on the conceptual underpinnings of the legislative reforms introduced in 1995. However, business is equally cognisant that the concept of regulated flexibility, as Cheadle observes, inherently recognises the diverse and dynamic nature of the labour market, and requires that regulatory frameworks should be capable of adaptation to meet the demands of changing circumstances.

Cheadle suggests that the essence of regulated flexibility is not simply a balance between two sets of interests rather than the framework, within which the balance is struck, using appropriate mechanisms to achieve this. From a business perspective, what is central 
to any future labour market reform is an assessment of the continued appropriateness of the limits within which the mechanisms by which the balance between employer and employee interests is struck. In this sense, the focus of labour law reform should not be viewed only from the perspective of any need to extend protection or limiting intervention where there is no appreciable gain in protection. Rather, given the framework that has been created and the mechanisms to establish flexibility that do exist, the question is whether the existing limits and mechanisms continue to be appropriate, and whether the correct balance has been struck between considerations of economic advancement and social justice. ${ }^{1}$ In determining this balance, the regulatory burden imposed on small, medium and micro enterprises, and the extent, to which this burden obstructs economic growth and job creation, must be a prime consideration. This may require mechanisms and their application to be reviewed.

For example, one of the mechanisms identified by Cheadle is the selective application of legislative standards or requirements. So while the exclusion of employers employing less than 50 employees from Chapter III of the Employment Equity Act is an example of the application of this mechanism, one might question why the same mechanism (the selective application of standards) is not applicable to unfair dismissal laws. If the logic underlying the mechanism of selective application of labour standards in this instance is to acknowledge the particular interests and difficulties of employers employing less than 50 employees (call them small employers) that logic should be tested in relation to standards other than the obligation to implement employment equity programmes. The test in each case should be whether the obligation imposed sets standards or obligations that pose particular problems having regard to the size of the undertaking concerned, and whether the nature and extent of these warrant limitation or even exclusion. Similarly, most supervisory and managerial employees are excluded from hours of work provisions in the Basic Conditions of Employment Act. The rationale for this exclusion is the bargaining power generally enjoyed by the class of employees able to negotiate the terms of their employment contracts. That being so, why should the same exclusion not apply to unfair labour practices, or to unfair dismissal laws? Employees who are able to negotiate their hours of work and rights to any payment for overtime work ought to be capable of negotiating rights to security of employment.

1 These are the words used in the preamble to the Basic Condition of Employment Act 
What this paper attempts primarily is a review of the existing legislative and regulatory package, questioning where necessary the appropriateness of the continued application of the limits and mechanisms that are intended to promote regulated flexibility, and reviewing the balance that the existing legislation seeks to achieve.

This paper does not purport to present the mandated views of organised business or any other component of the business constituency, rather than to raise for discussion general and specific issues that might be relevant to the debate initiated by Cheadle's paper.

There are further elements to this disclaimer - the issues identified for discussion are raised by a labour lawyer and not a labour economist. The view of the labour market presented in this paper is, therefore, one presented through a legal lens, but hopefully one that does not entirely filter out the social, political and economic dynamics that are fundamental to any debate on labour market regulation in South Africa.

Finally, this paper does not respond in specific terms to Cheadle's extensive analysis of the constitutional regulation of labour rights. As Cheadle has noted, the Constitution imposes significant constraints on the nature and extent of any deregulation of the South African labour market that might be advocated. Cheadle's analysis of the constitutional right to fair labour practices provides an insightful and pragmatic basis on which to test any proposals that may emerge from this process, and little purpose would be served by repeating or making further reference to that part of his concept paper. 


\section{South African Labour Laws: An Overview and Perspective}

\subsection{Perspectives and Constraints}

Government's objective to halve unemployment within a decade is premised on economic growth. Concern has been expressed that in the absence of a regulatory framework conducive to job creation, any higher rates of investment will favour capital intensive methods and industries, resulting in jobless growth. The current system of labour market regulation has been identified as a relevant (but not the sole) factor in this equation. Greater labour market flexibility is regarded by many as necessary for job creation, particularly by small and medium enterprises. These views are not confined to the South African private sector. The IMF, World Bank and other institutions have long argued that a more flexible labour market in South Africa would benefit job creation, and create an environment conducive to the growth of small businesses.

However, few of the proponents of this view have been specific about the legislative or other changes that might be necessary to achieve the flexibility for which they argue, and few pragmatic proposals for reform have been tabled.

Contrary to what has almost acquired the status of received wisdom, this paper argues that in comparative terms, South African labour laws are not as rigid and inflexible as many have suggested, and that the concept of regulated flexibility remains valid as a means of ensuring a balance between worker protection and economic efficiency. In other words, the basic conceptual model underpinning South Africa's labour laws remains intrinsically sound.

It follows that this paper does not suggest, as some who argue from a business perspective have done, that labour law reform in South Africa requires engagement in a form of regulatory arbitrage in which government seeks to attract foreign direct investment by setting lower levels of labour regulation.

The proponents of this view generally adopt one of two perspectives on labour market regulation. The first assumes that labour legislation is akin to an alien plant species, invading the perfectly adequate landscape of the common law and imposing unwanted and unwarranted regulation on the freedom to contract in the market place on equal terms. 
This is the view articulated by the Free Market Foundation, and suggests that laws intended for the protection of workers have the unintended consequence of protecting the employed at the expense of the unemployed. On this basis, any statutory regulation of the labour market is regarded as inconsistent with what is referred to as the 'right to work under any conditions'. This implies that the real choice for policy makers is between allowing workers to work on any conditions they are willing to accept, or forcing them to be unemployed against their will. Worker protection in this sense is that afforded by the common law (which is regarded as effective and adequate) and a resultant 'sellers' market' in which employers will be required to compete for labour by offering everimproving terms and conditions of employment (see Louw 2005)

Its merits (or lack of them) from an economic perspective aside, free market fundamentalism is not compatible with the principles that underpin our constitutional democracy. The Constitution specifically recognises the inadequacy of the common law and requires legislative intervention to correct imbalances in the labour market.

A similar but more sophisticated argument for the deregulation of the South African labour market assumes linkages between lower labour standards and competitive advantage in the global market. Comparisons are drawn with other economies, particularly those in Asia, seeking to compete for access to world markets and investment, often through a form of labour market deregulation that entails a significant lowering of labour standards.

There are a number of reasons why this approach is inappropriate to any reconsideration of labour market regulation in South Africa (Flanagan 2003). First, it is increasingly apparent that there is no empirical evidence to support the view that gains in trade performance or foreign direct investment are associated with lower labour standards. Core labour standards do not play a significant role in shaping trade performance (Lee 1998). In other words, there appears to be no comparative advantage to be had from the denial or violation of core labour standards (Hepple 2005: 14-15).

Research indicates that the contrary is true. The 1996 OECD Report concludes “... the clearest and most reliable finding is in favour of a mutually supportive relationship between successfully sustained trade reforms and improvements in association with bargaining rights" (Hepple 2005: 111-112). 
In his analysis of labour standards and competitive advantage published in 2003, Flanagan concludes:

"Contrary to the race to the bottom hypothesis, the analysis did not find significant linkages between export performance or FDI inflows and the measures of labour standards. In sum, the paper finds no evidence that countries with lower standards gained competitive advantage in international markets. Poor labour conditions often signal low productivity or are one element of a package of national characteristics that discourage FDI inflows or inhibit export performance." (Flanagan 2003: 17).

This is not to suggest, however, that there is no linkage between inflexible labour markets and the stifling of job creation. On the contrary, a recent co-publication by the World Bank and the International Finance Corporation quotes a study that suggests that in OECD countries with flexible labour laws, employment rates are $2-2.5$ percentage points higher (Doing Business 2006).

Labour economics aside, there are a number of external limitations on the nature and extent of any deregulation of the South African labour market. First, South Africa is a member of the International Labour Organisation. Since 1994, South Africa has ratified the ILO's entire core Conventions. In doing so, it has incurred international law obligations to uphold the rights to freedom of association, to engage in collective bargaining, equality at work, and to eliminate forced labour and child labour. South Africa is also bound by the Declaration on Fundamental Rights at Work, adopted by the International Labour Conference in 1998. The Declaration binds states, by virtue of their membership of the ILO, to observe the principles that underlie certain core Conventions. The package of labour law reforms introduced in 1995 were specifically tailored to anticipate the ratification of the core ILO Conventions, and thus to meet South Africa's international law obligations.

Secondly, as Cheadle observes, and as noted above, we live in a constitutional state in which the constitution recognises labour rights, and in particular the right to fair labour practices, as fundamental rights. The constitionalisation of labour rights implies that social justice is both the goal and the precondition for creating a durable economy and society, and thus places obvious limitations on the policy choices open to those who seek to regulate the labour market. Labour market policy is not a matter only of economics; choices are constrained by the terms of section 23 of the Constitution and the need to justify any limitation on the rights that it confers. 
In summary, empirical evidence suggests that from a business perspective, the competitive bidding down of core labour standards, either to attract new investment or to retain existing investment, is not a viable policy option. In any event, given the constraints of international obligations and the Constitution, this is not the basis on which any fundamental review of South African labour market regulation can be premised

However, this paper suggests that within these constraints, there are a number of measures that might be adopted and implemented, all of them consistent with international standards and all of which accord with common international practice, that will introduce greater flexibility (particularly to the benefit of SMME's) and profoundly affect employer and investor perceptions about the nature of labour market regulation in South Africa. The implementation of these measures will introduce adaptability into the labour market, but in a way that keeps the model of regulated flexibility and the integrity of core labour standards and rights to work security intact. First, though, it is necessary to examine the extent to which South African labour laws are out of alignment with those in other economies, if only to determine the nature and extent of any adaptation that may be appropriate.

\subsection{How Inflexible is South African Labour Legislation?}

The South African labour market is frequently cited in international studies as amongst the world's most rigid. The World Economic Forum's 2005-2006 Global Competitiveness Report ranks South Africa 40th (out of a total of 119) on the Global Competitiveness index, but places South Africa $115^{\text {th }}$ (out of 117 ) in relation to the flexibility of hiring and firing practices, $106^{\text {th }}$ in relation to the flexibility of wage determination (determined on a scale reflecting centralised bargaining process on the one end to individual company determination on the other) and $104^{\text {th }}$ in co-operation in labour-employer relations, measured on a scale from generally confrontational to generally co-operative.

On the other hand, South Africa fares well in the measures of protection of minority shareholders' interests $\left(15^{\text {th }}\right)$, foreign ownership restrictions $\left(29^{\text {th }}\right)$ strength of auditing and accounting standard $\left(5^{\text {th }}\right)$ and importance of corporate social responsibility $\left(8^{\text {th }}\right)$. 
The recent World Bank publication "Doing Business in 2006" ranks countries according to a number of criteria associated with the ease of doing business, including 'hiring and firing workers'. South Africa is scored as follows:

- Difficulty of hiring index (0 to 100$)$

- $\quad$ Rigidity of hours index (0 to 100$)$

- Difficulty of firing index (0 to 100$)$

- Rigidity of employment index (0 to 100)

- $\quad$ Hiring cost ( $\%$ of salary)

- $\quad$ Firing cost (weeks of salary)
56

40

60

3

38

While the methodology utilised in these studies is not always apparent, their accuracy, particularly in regard to hiring and firing practices, must be questioned. ${ }^{2}$

For any South African labour lawyer with some experience in comparative law, the conclusions drawn in the above and similar studies have always been enigmatic.

The broad legislative framework is similar to that found in many other jurisdictions, including those in the SADC region. The other point to make here is that the flexibility of other labour markets, especially those in Asia, were often exaggerated. In Europe, flexibility measures have most often concerned the relaxation of social security benefits (which are by comparison virtually non-existent in South Africa) and removing limitations on the use of temporary employment (also virtually non-existent in South Africa).

2 Information on labour market issues published in the World Bank publication appears to have been furnished by local firms of attorneys. While the indices used in the report are not apparent, the ratings seem highly suspect. For example, fixing the 'firing cost' index at 38 weeks' salary is patent nonsense- the Basic Conditions of Employment Act prescribes a severance package, payable only in the event of retrenchment, of 1 week per completed year of service. If the index refers to notice requirements, the maximum notice period contemplated by the Act is 4 weeks. If the index refers to compensation awards for unfair dismissals, these are payable only when a dismissal is found to be unfair and as research indicates, the average award is 6 months' (26 weeks) remuneration where a dismissal is found to be both substantively and procedurally unfair. (See the Tokiso Report at p 47) 
This is a conclusion that is supported by recent research. A survey of employment practices in OECD countries calls into question the conclusions reached in the World Bank and other studies. Benchmarking South African labour legislation against indices utilised in other more definitive studies, the comprehensive study recently undertaken for the 2004 edition of the OECD Employment Outlook suggests that South African unfair dismissal laws are not significantly less flexible than those applicable in most OECD countries.

For example, in relation to prescribed notice periods and severance pay, the severance pay payable to a worker with 20 years service in South Africa is 20 weeks (or 4.3 months) compared with France (4 months) Greece (white collar workers 8 months) Hungary (5 months) Ireland (41 weeks), Portugal (20 months), Spain (12 months) Turkey (20 months) and the United Kingdom (20 weeks).

The period of notice required in these circumstances (4 weeks in terms of section 37 of the Basic Conditions of Employment Act) is amongst the shortest notice periods required - compare United Kingdom (12 weeks), Switzerland (3 months), Portugal (60 days), Hungary (90 days) and France (2 months). ${ }^{3}$

In a comparison of the conditions under which individual dismissals are fair or unfair, all of the jurisdictions reviewed have some form of unfair dismissal protection. The most rigid protection of employment security is found in Mexico, where dismissals are fair only if the employer can demonstrate the worker's lack of integrity or action prejudicial to the company's interests, and where redundancy or poor work performance are normally not legal grounds for dismissal. ${ }^{4}$

In relation to what is termed a 'trial period' (periods during which there is no protection against unfair dismissal) most countries report the application of periods of 3-12 months. Only New Zealand is reported to provide for immediate coverage of labour legislation from inception of employment, and for probation periods that do not affect the application of fair dismissal laws. (South African law similarly provides for immediate coverage on identical terms).

3 This is a comparison of countries that require notice periods in addition to payment of severance. In some instances, these are not separate obligations. In Germany for example, a worker with 20 years service qualifies for 7 months' notice but no separate severance package. In Sweden, 6 months notice is prescribed but no severance package.

4 Despite these limited grounds on which dismissals can be effected, Mexico is rated 97th on the World Competitiveness report scale, in comparison to South Africa's 115. 
Virtually all jurisdictions reported that reinstatement was a potential remedy for an unfair dismissal. Exceptions were Finland (no reinstatement, compensation of 3-24 months) and Belgium (typical compensation at 20 years service 8 to 21 months, depending on white or blue collar status). Countries where reinstatement is the norm or frequently applied include Japan, Korea, Portugal, Poland, Greece, Hungary, Czech Republic and Austria. (In South Africa, reinstatement is ordered in only 36 per cent of successful unfair dismissal claims) (Tokiso Report).

The most marked differences in labour market regulation when comparing South Africa with OECD countries concern the use of temporary employment.

South African law is similar to that of Australia, where no restrictions exist on the use of fixed term contracts either in respect of the number of renewals permitted or cumulated duration, but where the risk of continual renewal may lead to a court finding that the primary purpose of the renewal is to avoid unfair dismissal laws. Australia is accorded the highest score on the flexibility rating, in relation to the use of temporary employment, together with Canada (no restrictions), Poland (no restrictions until accession to the EU, then 2 successive fixed term contracts allowed), Switzerland (same as South Africa) the United Kingdom (no restrictions for up to 4 years, after which the worker is treated as a permanent employee), and the United States (no restrictions).

Unlike South Africa, most OECD jurisdictions place significant limits on the use of temporary work, for example, by requiring the employer to establish some objective reason for requiring temporary work, or limiting the engagement of temporary workers to objectively defined circumstances e.g. a temporary increase in workload, specific tasks or projects, and replacements.

The OECD ratings in respect of the regulation of temporary work agencies reflect a similar pattern. In South Africa, there is a minimal obligation to register, and the assumption by the agency of joint and several liabilities with its client for certain wage related obligations. Mexico and Turkey score lowest in this section of the OECD ratings - temporary work agencies are simply not allowed to operate (in the case of Turkey, they are permitted only in the agricultural sector). Many other countries impose restrictions according to sector (in Korea, for example, temporary work agencies may operate only in relation to 26 defined occupations), or impose similar restrictions to those that apply to fixed term temporary work.

Finally, the OECD study compares the procedures for collective dismissals, and lists notification requirements. All of the member states reviewed have notification, information 
and consultation requirements. But the most instructive comparison in the context of collective dismissals is that of delays before notice can start and other special costs. The vast majority of member states require 'waiting periods' before notice can commence running. The most common period is 30 days (Norway, Netherlands, Ireland, Denmark, Belgium, and Austria) but some extend to 45 days (Italy and Poland), 75 days (Portugal) and 2-6 months (Sweden). In some countries, e.g. Spain, the approval of labour market authorities to dismiss is required in the absence of agreement with employee representatives, before any dismissal may be effected. These periods compare favourably with South African law, even where section 189A (and its 60-day moratorium on dismissal) applies.

In summary, and while this paper does not purport to be a definitive comparative study of the flexibility with which hiring and firing can be accomplished by an employer or of the costs associated with the existence and application of unfair dismissal laws, the OECD study illustrates, at least in respect of termination of employment, that the labelling of South African labour legislation as unduly restrictive and overly rigid may be misconceived. The OECD study, while by definition confined to OECD states, also calls into question the validity of the methodology adopted by the World Competitiveness report and similar studies (such as that contained in the World Bank's ("Doing Business in 2006") both of which tend to cast South African dismissal laws as onerous, inflexible, and far out of alignment with developed and developing economies elsewhere.

Further comparative research, using objective and accurate indices such as those developed by the OECD and in which South African laws are compared and ranked against those applicable in other jurisdictions, would benefit any review of domestic labour market regulation, if only to dispel negative perceptions and restore a greater degree of balance to the debate.

Further comparative research might also highlight the extent to which other aspects of labour market regulation, including the regulation of collective bargaining and wage flexibility, compare with international norms. Those comparisons may well indicate (as a cursory review suggests) that in theory at least, South African law is not significantly out of alignment with other jurisdictions. 


\section{Refining the Balance: A Review of the LRA and BCEA}

\subsection{Introduction}

None of the views expressed above suggest that there is no need for the revision and refinement of South African labour legislation, or that dismissal laws in particular should not be revised and adapted to ease the burden on SMME's. As Cheadle and others have argued, developments since the new legislative package was introduced in 1995 have witnessed a number of unintended consequences. Dispute resolution structures have been inundated with an unanticipated number of disputes, delays in determining disputes are commonplace, the cost of dispute resolution (both for the state and in terms of cost to the employer) is high, and proceedings before dispute resolution agencies and Courts are overly technical. All of these issues have a particularly severe impact on small business, which is least able to apply the resources required to address them.

But these are not fundamental issues, and can be addressed with relatively minor changes to legislation and other regulatory measures. The principal argument in this paper is that while the fundamentals are sound, international labour standards recognise and admit greater degrees of flexibility than are generally recognised, and that the mechanism of the selective application of labour standards in particular can be better utilised to recognise on a more consistent basis the interests of particular categories of employers (especially small employers) and categories of employees in respect of whom regulation (both statutory and administrative) and judicial intervention is not justifiable.

If international standards and practice specifically recognise the particular interests of SMME's, why has South African labour legislation not incorporated this recognition? There are exceptions - smaller employees are effectively exempted from the affirmation action requirements imposed by the Employment Equity Act, some leeway is extended by the Basic Conditions of Employment Act and sectoral determinations, but in general terms, dismissal laws draw no distinction between SMME, and larger employers. The only exception is in relation to retrenchment, where employers who engage less than 50 employees are excluded from the more onerous regulatory regime introduced in 2002. The reasons for a failure to consider the exclusion of particular categories of workers from unfair dismissal laws is probably historical - labour legislation, even where this has been separately applied to specific sectors e.g. agriculture and education has typically extended protection to all workers. Although the mechanism of selective application of labour standards has been applied in relation to basic conditions of employment, it has 
never been seriously contemplated in respect of employment security rights and it is in this respect that a review is now both appropriate and necessary.

The comparative studies disclose the following commonly applied mechanisms in regulating work security laws:

- Qualifying periods, in which employees are protected against the infringement of fundamental rights but enjoy no further protection against dismissal

- The exclusion of small business (usually defined by numbers of employees) from unfair dismissal laws.

As noted above, this paper suggests that a number of limited amendments to legislation and practice will have the effect of fundamentally altering employer and investor perceptions, increasing labour law flexibility and producing returns for job creation, all within the constraints of international and constitutional obligations. Revised mechanisms for regulation and proposed legislative and regulatory amendments are discussed below.

\subsection{The Individual Employment Relationship}

\subsubsection{Protection of Work Security - Unfair Dismissal Laws}

It was noted above that any proposals for the reform of unfair dismissal laws are constrained by international obligations and domestic constitutional imperatives.

Turning first to international obligations, although South Africa has not ratified ILO Convention 158 (Termination of Employment Convention 1982 (No. 158)), the Convention forms a useful benchmark against which South African labour law can be measured, and will no doubt inform any judicial consideration of the constitutionality of domestic work security laws or amendments to them In this section, Chapter VIII of the Labour Relations Act, in so far as it relates to unfair dismissal, is reviewed with reference to international standards. The section concludes with the observation that significant amendments could be made to Chapter VIII, consistent with international standards, which would promote greater flexibility in the exercise of workplace discipline. 


\section{a. The Scope of Application of Unfair Dismissal Laws}

The first point to make about the Convention is its scope of application. In general terms, the Convention applies to all branches of economic activity and to all employed persons However, a member state ratifying the Convention may exclude the following categories of employed persons from some or all of the provisions of the Convention.

- Workers engaged under a contract of employment for a specified period of time or a specified task.

- Workers serving a period of probation or a qualifying period of employment, determined in advance and of reasonable duration.

- Workers engaged on a casual basis for a short period.

The Convention requires that adequate safeguards must be provided against recourse to contracts of employment for a specified time the aim of which is to avoid the protection resulting from the Convention (General Survey 'Protection against Unfair Dismissal' 1994).

Article 4 of the Convention provides that measures may be taken by the competent authority after consultation with employer and worker organisations, to exclude categories of employed persons whose terms and conditions of employment are governed by special arrangements which provide protection at least equivalent to that afforded under the Convention. Here, the Convention has in mind persons with the status of public servants, who in many countries enjoy job security in terms of particular measures, often to an extent greater than that which applies to other employed persons. (General Survey 'Protection against Unfair Dismissal' Article 4(5) 1994).

Article 4 also permits measures to be taken to exclude from the application of the Convention other limited categories of employed persons 'in respect of which special problems of a substantial nature arise in the light of the particular conditions of employment of the workers concerned or the size or nature of the undertaking that employs them "(own emphasis). ${ }^{5}$

In other words, it is quite legitimate, in terms of the applicable international standard, for unfair dismissal laws to exclude from their application categories of employees to

5 The General Survey mentions, without being prescriptive, workers employed in family enterprises, managerial staff, workers who have reached the normal age of retirement, agricultural workers, apprentices, seafarers and domestic workers. 
whom it is particularly difficult to extend rights to work security and specifically to exclude employees engaged in small businesses.

Contrary to the flexibility recognised and extended by international standards through the mechanism of selective application, protection against unfair dismissal in South Africa extends to all workers, except those limited categories of persons excluded from the Act itself

Moreover, in South Africa, there is no qualifying period (workers enjoy protection against dismissal from the time that they enter into contracts of employment, even if they have not started work) (see Wyeth SA (Pty) Ltd v Mangle and others [2005] 6 BLLR 523 (LAC) probationary employees are not excluded from protection (the protection they are afforded is more limited - see below), and no categories of workers are excluded on the basis of special problems arising from their conditions of employment.

Many other jurisdictions identify and exclude categories of employees' from the application of unfair dismissal laws. International practice suggests that managerial employees, senior Government officials, and domestic workers are commonly excluded from the ambit of unfair dismissal laws. It is also not uncommon for unfair dismissal laws to be excluded from application to small businesses. For example, in Germany, the Protection against Unfair Dismissal Act does not normally apply to enterprises employing less than 6 workers. In Australia, recent amendments to labour legislation will have the effect that businesses with up to and including 100 staff will be exempt from unfair dismissal laws. The stated purpose of the amendment is to generate more job opportunities, on the basis that previous laws prevented businesses from hiring more staff (www.workchoices.gov. au).

\section{b. Senior Managerial Employees}

It is apparent from the discussion on the terms of Convention 158 that a category comprising senior managerial employees can legitimately be excluded from the state of unfair dismissal laws. At present, the Labour Relations Act draws no distinction between levels of seniority and work security rights. There is a perception, which appears to be conferred by the research reported in the Tokiso Report, that employees in this category make extensive use of the free services provided by the CCMA if only to pressure their employers into lucrative financial settlements. 
In terms of international norms it is not uncommon to exclude senior managerial employees, usually defined by an earnings threshold. In Australia, non-award employees earning over a defined threshold are not covered by unfair dismissal law. These exclusions are premised on the basis that employees in these categories are able to negotiate adequate protections in terms of the contractual arrangements that they conclude with their employers. The limitation of work security rights by reference to an earning threshold should be further considered.

\section{c. Fair Reason for Dismissal: Incapacity: Probation}

Cheadle suggests that probation is a 'vexed issue'. There would be few employers who would disagree with that proposition.

In general terms, probation is a legitimate mechanism for an employer to assess the competence and suitability of an employee before confirming that employee in permanent employment. Article 2(2)(b) of the Convention recognises the legitimacy of a probationary requirement, provided that it is determined in advance and is of reasonable duration. (Probationary periods should be distinguished from qualifying periods. A qualifying period is a period, during which there is no protection against dismissal for any reason, except possibly those that infringe fundamental rights. A probationary dismissal is effected during or shortly after a contractual or statutory probationary period and is related to the capacity or compatibility of the worker).

The 1995 draft of the Code of Good Practice: Dismissal was silent on probation, and the intention was that commissioners would use the injunction to depart from the norms established by the Code to establish a set of rules regulating employer and employee rights during periods of probation. As Cheadle observes, that did not occur. As a result, the Code was amended in 1998 to stipulate that a probationary period of reasonable duration was permitted, subject to a number of specifically identified obligations on the part of the employer. (These included the obligation to provide appropriate training, instruction, opportunity to improve, etc).

Despite this more specific guidance, commissioners have failed to develop a coherent set of guidelines based on the revised Code. The approach adopted in the CCMA (which was effectively to draw no distinction at all between an employer's obligations pre- and post probation) promoted a leading author to comment that a probationary clause in a contract of employment wasn't worth the proverbial paper it was written on. 
In 2002, the Code of Good Practice was again amended. The amendment introduced a requirement that appears to require a lower substantive hurdle for the employer to jump in any litigation- the commissioner is enjoined to accept reasons for a performance-related dismissal that may be less compelling than those that might be required in a dismissal effected after the completion of a probationary period. At the same time, the definition of unfair labour practice was amended, effectively to prohibit unfair employer conduct in relation to probation. Paradoxically, if an employer dismisses an employee for misconduct during a probationary period, there is no relaxation in the standard that applies.

As Cheadle observes, the amendment was no doubt driven by union fears that employers would simply continue to extend periods of probation, thus denying workers permanent employment. This concern does not appear to have materialised, but the amendment has had the effect of creating even greater uncertainty than that which previously applied.

Cheadle proposes that a more effective method of regulating probation is for the employer to eschew a probationary period of employment and conclude instead a fixed term contract, and determine during the period of the contract whether the employee is suitable for permanent employment.

Although this is a mechanism that is currently available to employers (provided of course that the employee agrees to the fixed term appointment) it does not entirely remove existing inflexibilities in relation to probation. The definition of dismissal in section 186 of the Labour Relations Act contemplates a refusal to extend a contract of employment in the face of a reasonable expectation by the employee to this effect. While there is some uncertainty as to whether this expectation can, for the purposes of the section, extend to an expectation of a permanent appointment, it may well be that the use of the mechanism of a fixed term contract to assess employee suitability and performance may result in a dispute over any refusal to make a permanent appointment or extend any fixed term contract. In this event, the reasons for the employer's refusal (i.e. the employee's incompatibility or failure to meet required performance standards) may well become the substantive basis on which the dispute will have to be determined, raising the same issues that currently plague the assessment of fairness in probationary dismissals.

A more satisfactory solution to the probation issue is the exclusion of the application of the ordinary dismissal laws (i.e. other than for reasons that are automatically unfair) for a specified period. What is proposed here is a qualifying period, which will permit employers to make decisions about the suitability and capacity of newly appointed employees and 
dismiss them for those reasons, without right of recourse, before the qualifying period expires.

Cheadle appears to endorse the concept of a qualifying period, but suggests that this should apply only to the employee's initial employment, i.e. that in relation to second and subsequent jobs, the qualifying period does not apply. If a qualifying period is to replace the confused regulation of the rights of probationary employees, there is little point in applying this restriction. Each employer will want to be satisfied that a newly engaged employee is suitable for continued employment. On this basis, qualifying persons should apply to each engagement as an employee with a different employer. It will be necessary of course to devise mechanisms to protect the fundamental rights of employees in qualifying periods (equality rights, freedom of association, etc) and to present other employer abuse (routinely dismissed just prior to the end of a qualifying period etc).

As noted above, international standards and practice recognise the legitimacy of qualifying periods.

Having said this, there is no reason why qualifying periods and probationary periods should not co-exist, particularly where a qualifying period is shorter than the time it would take to reasonably assess the suitability of a newly appointed employee. In this instance, employers would have the benefit of a statutory qualifying period within which to assess performance and suitability for permanent appointment, but they could also be entitled to incorporate contractual probationary periods during which they could continue to assess employees for permanent appointments. In other words, probation would be regulated by contract; qualifying periods would be regulated by statute. Any abuse of either should be regulated by contractual and statutory remedies respectively.

The incorporation in the LRA of a qualifying period of not less than 6 months, ${ }^{6}$ and the exemption of SMME's from unfair dismissal laws are the single measures that would do more than most others to remove conceptions of inflexibility that exist in relation to South African dismissal laws.

\section{d. Fair Procedure}

Anecdotal evidence suggests that the requirements of procedural fairness have contributed more than any other factor to perceptions about the inflexibility of South African labour law. It is also the area of labour law where labour consultants and other self styled labour

6 In comparative terms, 6 months is a relatively short period. 
practitioners are best able to misrepresent the applicable legal requirements as more complex than they actually are, thus creating and sustaining the perception that exercising workplace discipline is a matter that can be accomplished only by professional advice. ${ }^{7}$

When the Labour Relations Act was drafted in 1994, the drafting team reviewed the law on unfair dismissal law as it had evolved during the 1980's. To some extent, Chapter VIII of the Labour Relations Act represents a codification of that jurisprudence. But it also represents a number of trade-offs, and ultimately, the delicate balance that is reflected in both the Act and the Code of Practice.

The trade-off related primarily to procedural requirements (which were consciously relaxed), remedy (where reinstatement was fixed as the primary remedy) and the capping of compensation (generally 12 months, and 24 months for dismissals where the reason is automatically unfair).

In regard to procedural fairness, the logic of requiring minimal procedural requirements at workplace level was to avoid a duplication of procedure. There is little sense in requiring an employer to conduct an adversarial type hearing akin to a criminal trial and then, in the event that the employer's finding is challenged, to repeat the process, in the same adversarial manner, before an arbitrator, particularly where the arbitrator is required to determine the dispute on the merits. The retention of significant procedural obligations in the workplace would have been justified only by limiting an employee's rights of recourse to a more limited review of the employer's substantive decision.

The rules relating to procedural fairness, introduced in 1995, recognised that for workers, true justice lay in a right to an expeditious and independent review of the employer's decision to dismiss, with reinstatement as the primary remedy where the employer was found to have made the wrong call.

For employers, this right of resort to expeditious to independent arbitration was intended not only to promote rational decision making about workplace discipline, but also to limit exposure to open-ended claims for compensation. The balance struck in this instance recognised not only that employers were not magistrates, that to require a hearing at a

7 See for example the newspaper columns written by labour consultants in publications such as The Star's supplement 'Workplace' where topics for discussion often include the more arcane aspects of the law of evidence, which are presented as integral and necessary requirements of any disciplinary process on the day of writing this paragraph, the worker received an invitation to a seminar, part of a series being conducted countrywide and under the auspices of a legal publisher, on the law of evidence in disciplinary enquiries. 
level that would make a Judge proud was impractical, but also that workplace efficiencies should not be unduly impeded by onerous procedural requirements.

For reasons that remain unclear, the old industrial court jurisprudence on procedural requirements continues to be applied. Employers continue to engage in adversarial hearings in the workplace. When a dismissal is challenged, there is a rehearing before a commissioner, on the merits and on the evidence presented on the day. In this model, procedural requirements in the workplace become reduced to a requirement of fair procedure for the sake of fair procedure - the workplace proceedings do not affect the merits of the case presented at arbitration and serve only to fulfil the requirement that a fair procedure be applied prior to dismissal.

This more than many other factors gives rise to perceptions about inflexibility in South African labour law. It is the zone in which self-styled labour consultants and other carpetbaggers ply their trade, and in which employers, particularly those in smaller businesses, are the victims of misconceptions and misrepresentations as to what fair procedure actually requires. ${ }^{8}$ It doesn't help, of course, that for reasons which remain unclear, some CCMA commissioners continue to perpetuate the same misconceptions by applying a stricter level of workplace procedure than that which is required by the Code of Practice.

These views are substantiated by recent research. The 2005 Tokiso Report on Dispute Resolution finds that 78 per cent of those cases in which findings are made against employers incorporate an element of procedural unfairness. The study concludes that the most likely interpretation of these figures is an intense focus on the minutiae of procedure that currently beset allegations of unfair dismissal (Tokiso Report: 38).

8 These misconceptions are not limited to small businesses. It is not uncommon to find workplace disciplinary enquiries being conducted by counsel, particularly when senior employees are charged with misconduct. The author has encountered cases where the employer, a parastatal, budgeted R1 million per hearing for the purpose. The irony is that all of these hearings, chaired a senior counsel assisted by a junior counsel each for the employer and the employee, where they result in dismissals, are then referred to the CCMA. The subsequent arbitration (which is a re-hearing and which results in a binding award) is likely to be conducted before a commissioner who has no legal qualification at all. The author is also aware of employers who use internal disciplinary hearings as a strategy to oust employees who for whatever reason, are no longer in favour but who have committed no misconduct. In these cases, an independent legally qualified chair is appointed, a legal representative appears for the employer, and the employee is left to find a legal representative for him or herself. Employees are easily and quickly bankrupted in the process. Here, the policy objectives of the Act (social justice) are frustrated by the use of a purposeless process (the workplace disciplinary enquiry). If the model adopted by the LRA were to be applied, abuse of this nature would be circumscribed. 
The Report suggests:

"There is a widely held belief at present, albeit anecdotal, that procedural fairness is being interpreted and applied by CCMA commissioners in afar more rigorous manner than is required by the Code of Good Practice on Dismissal annexed to the LRA.

This seems to be spurred on by employers, who seem to think that they are obliged to follow court-like proceedings in disciplinary hearings, as well as employees (and their advisors) who argue procedural fairness on the most obscure of technicalities.

It is commonly held that on order to effect a procedurally fair dismissal, the employer must ape the procedure of the High Court, and meet the same standard of justice. The notion of 'simple industrial justice', and its echoed (sic) in the Code of Good Practice, seems to have been lost. Employers' (sic) have adopted complex disciplinary procedures which outline the most detailed process to follow. Employees and unions are also to blame, demanding the most obscure procedural rights from employers.

Overall, the net beneficiaries of this proceduralism appear to be consultants and lawyers and the 'Labour Law' Organisations who pass themselves of (sic) as experts in labour law or as being 'labour litigators'.

Equally, an analysis of the awards tends to support the fact that some Commissioners seem to expect a standard of procedural fairness akin to court procedure, all of which has, undoubtedly fed the employer tendency to outsource labour and operate in the grey labour market".

International standards, in the form of Convention 158, require procedures to promote compliance with the obligation to ensure that dismissals are based on valid reasons. These procedures are divided into two categories - those to be observed before or at the time of termination, and those governing appeals against termination. (Note that 'appeal' in this context means a right of recourse to an independent and impartial body, such as a court, labour tribunal, arbitration committee or arbitrator. This should not be confused with the right of an internal appeal to a higher level of management that is common in South African disciplinary codes and procedures.) 
The Convention provides that "the employment of a worker shall not be terminated for reasons related to the worker's conduct or performance before he is provided an opportunity to defend himself against the allegations made, unless the employer cannot reasonably be expected to provide this opportunity“.

The ILO's Committee of Experts has observed that the Convention does not state explicitly what form this defence should take, or the form in which the allegations should be presented. In its last General Survey on the application of the Convention, the Committee of Experts observed that-

"It is clear from the preparatory work that the opportunity for a worker to defend himself is related to the possibility of his being afforded an opportunity to be heard by the employer, without there being a need for an adversarial proceeding. In reply to the proposed text submitted to the Conference by the Office and after the first discussion, which provided that the employment of a worker should not be terminated for reasons related to his conduct or performance before being afforded a hearing by the employer and given the opportunity to defend himself against the allegations made, three governments proposed to delete the reference in this paragraph to the word "hearing", which they believed implied a quasi-judicial procedure, with a view to greater flexibility. The Office pointed out that inasmuch as the word "hearing" might have such a connotation it felt that this reference could well be deleted without affecting the substance of this provision, according to which a worker should not have his or her employment terminated for reasons of conduct or performance before being given an opportunity to defend him- or herself against the allegations made.

[148] Over and above the terms of Article 7 and its meaning, which is to allow workers to be heard by the employer, the purpose of this Article is to ensure that any decision to terminate employment is preceded by dialogue and reflection between the parties."

9 Protection Against Unjustified Dismissal' General Survey, International Labour Conference 82 ${ }^{\text {nd }}$ Session 1995 
This was the conception of the right to a hearing prior to dismissal that was incorporated into the Code of Good Practice: Dismissal annexed as Schedule 8 to the Labour Relations Act. Item 4 of the Code provides:

"(1) Normally, the employer should conduct an investigation to determine whether there are grounds for dismissal. This does not need to be a formal enquiry (own emphasis). The employer should notify the employee of the allegations using a form and a language that the employee can reasonably understand. The employee should be allowed the opportunity to state a case in response to the allegations. The employee should be entitled to a reasonable time to prepare the response and to the assistance of a trade union representative or fellow employee. After the enquiry, the employer should communicate the decision taken, and preferable furnish the employee with written notification of that decision."

Sub-item 4(4) provides "In exceptional circumstances, if the employer cannot reasonably be expected to comply with these guidelines, the employer may dispense with predismissal procedures."

In summary:

- Despite attempts to define the requirements of fair procedure in the Code of Good Practice, evidence suggests that the adversarial approach developed by the industrial court in the mid1980 's continues to be applied by employers and enforced by the CCMA.

- The beneficiaries of this misconception, and those whose interests continue to be advanced by it, is the class of 'labour law consultants' that has emerged, and who with admitted legal practitioners provide advice on procedures that would do the High Court proud. In one sense, this is a chicken and egg situationadvice is given on the basis of what CCMA commissioners might expect.

- For as long as the CCMA applies and demands procedural rights beyond those required by the Code of Good Practice, consultants in their various guises stand to benefit, and the law will be represented as more complex than what the Code requires. Those most disadvantaged in this process are employers who have no internal expertise and are reliant on consultants' advice i.e. SMME's. 
- Research suggests that rigid procedural requirements has contributed significantly to employers resorting to the use of atypical labour.

- An amendment to the Labour Relations Act to reflect the standard of fair procedure required by Convention 158 and a proper regulation of the activities of labour consultants will do more than most others to dispel perceptions about labour market flexibility in South Africa.

\section{e. Dismissal for Operational Requirements}

The statutory requirements relating to a dismissal for operational requirements (usually retrenchment) are generally perceived by employers to suffer similar degrees of inflexibility to those that apply in the case of dismissals for misconduct and incapacity. The introduction in 2002 of a limitation on the right to dismiss in certain circumstances until the lapse of a 60 day period and the introduction of a right to strike over retrenchment disputes have done little to dispel these perceptions. Perhaps the most problematic element of the amendments is the distinction drawn between 'smaller' and 'larger' retrenchments, the differing substantive and procedural requirements that apply to each, and the bifurcation in procedure in the case of disputes about the substantive and procedural fairness of the retrenchment respectively. Recent Labour Court judgments illustrate the difficulties inherent in separately substantive and procedural fairness and providing a discrete procedure for each.

It is suggested in this section that while the introduction of section 189A into the Labour Relations Act specifically took account of the requirements of small business by excluding the application of the section to businesses employing less than 50 employees, the regulation of retrenchments is unnecessarily complex, and fails generally to meet policy demands pertaining to small business. Greater flexibility can be achieved, for small business and more generally, by amendments to section 189 and 189A, all of which can be effected to meet international standards and international practice, to exclude small businesses from consultation obligations.

Article 13 of Convention 158 provides that where an employer contemplates terminations for reasons of an economic, technological, structural or similar nature, the employer must provide workers' representatives with relevant information including the reasons for the terminations contemplated, the number and categories of workers likely to be affected and the period over which the terminations are intended to be carried out. In accordance 
with national law and practice, the workers' representatives must, as early as possible, be given an opportunity for consultation on measures to be taken to avert or to minimise the terminations and measures to mitigate the adverse effects of any terminations on the workers concerned.

Article 14 of the Convention requires an employer that contemplates terminations of employment for reasons of an economic, technological, structural or similar nature, to notify, in accordance with national law and practice, the competent authority as soon as possible, giving relevant information, including a written statement of the reasons for the terminations, the number and categories of workers likely to be affected and the period over which the terminations are intended to be carried out. This is probably the only respect in which South African law, in its current form, fails to meet the requirements of the Convention. Only the mining industry is subject to any reporting obligation.

However, section 189 of the Labour Relations Act prescribes in detail the procedures generally applicable to dismissals for operational requirements, and in doing so virtually mirrors the wording of the Convention.

The consultation and reporting requirements of Convention 158 are qualified by Article 13(2) which provides that the requirements prescribed above may be limited by the methods referred to in Article 1 of the Convention to cases in which the number of workers whose termination of employment is contemplated is at least a specified number or percentage of the workforce. In other words, the Convention specifically allows each member state to limit the application of consultation and notification requirements to instances in which the number of workers whose termination of employment is contemplated is at least a specified number or percentage of the workforce.

The ILO's Committee of Experts has noted that the Convention does not establish any specific quantitative criterion or threshold for the number of terminations of employment beyond which the procedures provided for in Articles 13 and 14 are applicable. This entitles a member state to prescribe that consultation and notification requirements apply where a single employee is the subject of a contemplated retrenchment (as is the case in South Africa), but it also permits a significant degree of flexibility which most member states have applied. The Committee has noted that in 'the large majority of countries', the consultation and notification procedures apply to the termination of the employment of a 
specified number of workers or percentage of the total workforce. ${ }^{10}$

This observation is supported by the OECD study (referred to above) which lists, by country, the definition of collective dismissal. In virtually each instance, the definitions limit notification requirements by reference to the number of employees whose dismissal is contemplated within a defined period. In most instances, a threshold is also applied by reference to the number of employees employed by the affected employer. So, in Ireland for example, in firms with 20 to 49 employees, consultation requirements apply if the employer contemplates dismissing 5 to 9 workers within any period of 30 days. For firms with 50 to 99 employees, the relevant figure is more than 10 workers, with a sliding scale thereafter depending on the number of employees.

The majority of jurisdictions surveyed appeared to exempt employers from notification and consultation requirements where less than 20 employees are employed. (e.g. Austria, Belgium, Denmark, Finland, Germany, Greece, Hungary, Switzerland and Turkey). Other countries have implemented higher thresholds e.g. Portugal (50 employees) and Korea (100 employees).

The Labour Relations Act does not provide for any of the thresholds contemplated by the Convention. South African employers are required to comply with the obligations to consult and to disclose information even when the retrenchment of a single employee is contemplated, and all of the consultation requirements prescribed by section 189 apply in this instance. The impracticability of this requirement is illustrated by those cases referred to the CCMA in which domestic workers are retrenched - in theory at least, the same substantive, consultation, and disclosure requirements that apply to a business employing 49 workers must be applied.

The only thresholds contemplated by Chapter VIII of the Act is the total number of employees engaged by the employer that contemplates retrenchment, and the number of employees that the employer contemplates retrenching. These thresholds are relevant only to the determination of whether or not a retrenchment falls to be regulated by section 189 or by section $189 \mathrm{~A}$ of the Act. In the latter instance, the 2002 amendments introduced the concept of the facilitation of retrenchment negotiations (which according to anecdotal evidence appears to be a relatively successful mechanism to secure consensus on the terms of proposed retrenchments), and the right to strike over the substantive grounds on

10 General Survey: "Protection against unjustified dismissal", International Labour Conference 82nd Session 1995 at para 277. 
which the employer relies to effect the retrenchment.

The formula to determine the applicability of section 189A is complex, and to some extent relieves small business of the burdens of a more prolonged consultation procedure as well as the exercise of any right to strike. However, a greater degree of flexibility, particularly for small business, may be achieved by implementing those terms of the Convention that permit a limitation of employer obligations depending on the numbers of employees to be retrenched.

In summary, in relation to substantive unfair dismissal laws:

- International labour standards recognise the legitimacy of the mechanism of the selective application of standards. They permit the exclusion of defined categories of employees from the ambit of unfair dismissal laws, and particularly recognise small business as a category appropriate for exclusion.

- Consistent with the policy purpose underlying regulated flexibility there would be no bar to the exclusion from protection of senior management, or as is the case in other jurisdictions, employees whose remuneration exceeds a threshold amount. Other categories of employees in respect of whom special problems can be identified (domestic workers, senior Government officials) are also capable of exclusion.

- There is no requirement, in either international standards or domestic labour legislation, for a formal hearing prior to dismissal. The adversarial system adopted by employers in South Africa when conducting disciplinary enquiries is inappropriate and represents an unnecessary duplication of process. There is no obligation to hold any internal appeal hearing. All that is required is that before taking a decision to dismiss, the employer affords the worker with an opportunity to express his or her point of view. If the employer decides to dismiss, the employee's right of recourse is to arbitration or adjudication if the dismissal is disputed.

- It would be entirely consistent with international standards to amend section 189 so as to provide for requirements of notification and consultation that apply only in the event that the employer contemplated, within a defined period, the termination of employment of a specified number of employees. 
- It is also legitimate to refine this requirement by reference to the size of the business. A provision of this nature would simplify the requirements of the Act, and facilitate a merged section 189 and 189A, applicable only to larger businesses or larger scale retrenchments than those currently regulated by the Act.

\subsubsection{Adjudicating Unfair Dismissals}

Any evaluation of the mechanisms for the resolution of dismissal disputes must necessarily take into account the enabling legislation, but more relevant in practice are the manner in which that legislation is implemented, and the extent to which non-statutory measures and factors either impeded or advance statutory objectives. A fuller discussion of the workings of the CCMA and Labour Courts is included below. This section, like those above it, compares relevant international standards with current practice, and raises for discussion considerations that might result in greater flexibility.

Articles 8 and 9 of Convention 158 deal with procedures relevant to appeals against terminations of employment. In essence, the Articles require that a worker who considers that his or her employment has been unjustifiably terminated is entitled to appeal against that termination to an impartial body, such as a court, labour tribunal or arbitrator. This right must be exercised within a reasonable period of time after termination.

Article 9 provides that the bodies referred to in Article 8 must be empowered to examine the reasons given for termination and to render a decision on whether the termination was justified. In regard to the onus of proof, two possibilities are established. First, the burden to prove the existence of a valid reason for termination rests on the employer, alternatively, that the body referred to in Article 8 is empowered to reach a conclusion on the reason for termination having regard to the evidence provided by the parties according to procedures provided for by national law and practice.

The Labour Relations Act requires conciliation prior to arbitration or adjudication, imposes time limits in respect of referrals of disputes at both phases, and places the onus of proof of a fair reason to dismiss on the employer. The system of adjudication that it contemplates, in most dismissal disputes, is relatively informal and was intended to be concluded with the minimum of legal formality. All of these provisions are consistent with international labour standards, and are not out of line with rights of recourse established in other jurisdictions. 
The Labour Relations Act also consciously seeks to establish an expeditious system of dispute resolution in dismissal disputes, and for that reason, imposes strict time periods within which disputes may be referred both for conciliation and for arbitration or adjudication. This was an integral element of the balance that was sought by the Act- the expeditious determination of dismissal disputes permits the application of reinstatement as a primary remedy, and avoids the prospect of protracted litigation where a determination of the dispute ultimately becomes a meaningless but costly exercise for both parties.

The recent Tokiso Report provides an analysis of the time taken in the dispute resolution process. The Report observes that, certainly with regard to dismissal disputes, the process was intended to be an expeditious one. Dismissals are required to be referred within 30 days of the date of dismissal, conciliation is required within a further 30 day period, reference to arbitration must be made within 90 day of the failure of conciliation, and the arbitrator's award is required within 14 days of the conclusions of the arbitration hearing.

The Report notes that the timing envisaged by the statute has proved to be largely unattainable. In the CCMA, more than half of the disputes were concluded in excess of 150 days from the date of referral. The report notes that it is "not uncommon" to find CCMA cases that were concluded in periods exceeding 300 days (Tokiso Report: 29).

The Report suggests also that the primary reason for the delay in the statutory dispute resolution process is the sheer number of referrals. Other reasons include the inefficient administration of cases, and in particular, poor administration by case management officers. The requirement that a dispute be referred to arbitration within 90 days has also frustrated expeditious dispute resolution, and the Metal and Engineering Industries Bargaining Council's practice of incorporating the referral to arbitration in the certificate of outcome is mentioned as a way of expediting this structural delay. Other delays are attributed to requests for postponement, and Labour Court reviews of in limine rulings.

The 2002 amendments to the Labour Relations Act sought to promote and improve the expeditious resolution of dismissal disputes by introducing section $188 \mathrm{~A}$, which permitted the parties, by agreement, to have allegations of misconduct that may lead to dismissal arbitrated in the workplace, with no recourse to the conventional statutory mechanisms.

Another alternative introduced by the amendments was the 'con-arb' mechanism, effectively designed to effect cost savings for the CCMA by collapsing the conciliation and 
arbitration phases into one. The Tokiso Report indicates that only 17 per cent of the total number of referrals to the CCMA and MEIBC for the period 2002 to 2004 were dealt with on the expedited 'con-arb' basis.

Is there a case for continuing to require separate conciliation and arbitration procedures? The Tokiso Report notes that there is no definitive data to indicate the costs to the individual employer who has had to defend an unfair dismissal claim in the CCMA, or who follows a particular procedural approach to a dismissal, in the belief that this is what the Labour Relations Act requires. The Report indicates that estimated employer costs associated with hearings taking misconduct cases only imply that around 1.6 million mandays (sic) are spent in misconduct processes alone. As the Report observes, this figure is very significantly higher than the impact of strike action on the total economy. The figures quoted in the Report are only in respect of employers, and take no account of the equivalent costs for trade unions in providing a service to their members.

The CCMA reports a settlement rate of 63 per cent for the current financial year. Of referrals 79 per cent are unfair dismissal disputes. Although these levels of settlement are commendable, questions of cost and efficiency must be raised given the dual nature of the dispute resolution process. The con-arb process has the advantage of eliminating the costs of two separately convened interventions by the CCMA, but retains the advantages of an initial attempt to conciliate a dismissal dispute or, in the absence of conciliation, to more closely define the issues in dispute. A cursory review of the costs of convening conciliation and arbitration hearings respectively would suggest significant savings both for the employer and worker parties to the proceeding, and to the institution.

\subsubsection{The Unfair Labour Practice}

\section{a. Introduction}

Amongst the most persuasive arguments in Cheadle's paper are those that relate to the definition of unfair labour practice. The dubious heritage of the concept has been documented (see Van Niekerk 2005). and as Cheadle observes, the definition currently contained in section 186 of the Labour Relations Act was in any event something of a stopgap. The anticipated discussion on the continued appropriateness of a list of what pertained at the time of drafting the Labour Relations Act that was intended to occur at the time of the drafting of the Basic Conditions of Employment Act never took place, and what remains, now in the body of the Labour Relations Act, is an arbitrary list of prohibited 
employer conduct. The list extends to promotion, demotion, probation, training and the provisions of benefits, suspension, disciplinary action short of dismissal, and the refusal to reinstate a former employee in terms of an agreement and an occupational detriment in contravention of the Protected Disclosures Act.

Cheadle highlights the charmed life that the concept of the unfair labour practice has led, and notes that having started out for the flimsiest of reasons, it spawned a jurisprudence, at least until 1995, developed on an ad hoc basis, and encompassing anything that could conveniently be placed within the broad language of its various definitions.

Cheadle is correct when he suggests one of the tasks of labour law reform should be an analysis of the concept of unfair labour practice and a review of the continued justification for the scope and remedy that the concept provides (Cheadle 2006). This is particularly so since the more comprehensive regulation of labour rights now obviously calls into question the continued need for further protection of a set of arbitrary individual rights. There are rights and remedies in respect of any breach of expanding rights (in terms of the EEA) and rights of freedom of association (in terms of the LRA). This is the extent to which the law ought appropriately to regulate employer conduct, and leaves for other mechanisms (e.g. collective bargaining) the prospect of extended those protections or recognising other rights worthy of protection.

In 2004/5, the CCMA reported that 7 per cent of disputes referred to that body concerned alleged unfair labour practices. The Tokiso Report notes that in the public sector, this figure is 53 per cent (Tokiso Report). This research would appear to support what has until now been anecdotal evidence to the effect that the unfair labour practice has been used by public sector employees to challenge appointments (or more accurately, nonappointments) to posts for which they have applied, promotion disputes, and disputes about employee benefits applicable in the public sector. ${ }^{11}$ (Interestingly, the Tokiso Report also notes that the success rate of employee claims in unfair labour practice disputes is consistently and significantly low, with employees enjoying a success rate of only 27 per cent.) (Tokiso Report).

11 Interestingly, the Tokiso Report also notes that the success rate of employee claims in unfair labour practice disputes is consistently and significantly low, with employees enjoying a success rate of only 27 per cent. 
Protection against unfair labour practices developed in an era where no specific statutory protection existed to prohibit unfair discrimination and to protect rights of freedom of association. Given the fundamental rights now established by the Labour Relations Act, and in particular the right to equality and the right to freedom of association, the continued protection against unfair employer conduct in relation to an arbitrary list of individual employment related issues must be questioned.

Each of the elements of the unfair labour practice definition is referred to below.

\section{b. Training}

Given the protection of fundamental rights in sections 4 and 5 of the Labour Relations Act and under Chapter II of the Employment Equity Act, there is no need for protection under the unfair labour practice.

\section{c. Promotion}

Similarly, given existing statutory protections, the application of the unfair labour practice to promotion disputes in superfluous.

\section{d. Demotion}

Demotion occurs most commonly in two instances. The first is where demotion is used as a disciplinary measure, as an alternative to dismissal. The other is where demotion represents the outcome of performance management processes. Demotion disputes are less frequent in the third instance Cheadle raises, a demotion effected as an alternative to retrenchment.

In all cases, demotion can be effected only with the consent of the employee. The contract of employment confers a particular status on an employee, and a unilateral variation of that status by the employer is a breach of contract.

The BCEA confers jurisdiction on the Labour Court to deal with contractual disputes. Contractual rules provide remedies in demotion disputes, and the Labour Court has jurisdiction to determine these disputes. There is accordingly no necessity for an additional remedy, based in principles of equity, to be conferred by statute. 


\section{e. Discipline short of dismissal}

This provision confers a statutory remedy on every employee who is issued with a warning, whatever its severity or lack of it, or on whom any other disciplinary penalty is imposed. It is not clear from the statistics available how frequently rights of recourse are sought under this provision, but Cheadle is correct to suggest that once an employer's power to dismiss is regulated by subjection to a test of fairness, there is no good reason to provide statutory protection to employees in these circumstances. Given the limited duration of warnings, even final warnings, disputes concerning the fairness of these will rarely be determined in any arbitration proceedings before the warning in any event lapses.

Where the employer relies on warnings issued arbitrarily and with the primary purpose of justifying a subsequent dismissal, the unfair dismissal provisions of Chapter VIII are adequate to protect rights to employment security in this instance.

\section{f. Benefits}

Employer conduct in relation to the provision of a benefit is probably the most vexed of the elements of the definition of unfair labour practice. The Labour Courts have interpreted the provision narrowly, so as not to cross the boundary between disputes of interest and disputes of right. In short, a dispute about a benefit, in terms of current jurisprudence, can only concern an existing right that arises in terms of either a contract of employment, or an existing law. It cannot form the basis of a new right, or any expectation of a new right. This being so, this element of the definition of unfair labour practice is unnecessary. Where the right has it's a contract as its basis, the employee is afforded contractual rights. Where the right is based in legislation, that legislation affords the basis of the remedy.

From a policy perspective, the state should have a role in prohibited employer conduct that infringes fundamental rights. In this context, these are rights of freedom of association (protection against victimisation) and the enforcement of the right to equality in the workplace. Where disputes fall outside of these parameters, they are best dealt with by other mechanisms, and in this instance, primarily by collective bargaining. ${ }^{12}$

12 There is no reason why the plethora of unfair labour practice disputes shouldn't be dealt with in terms of collective agreements that define the nature and extent of benefits to which employees are entitled, and which provide mechanisms for the resolution of disputes about the application and interpretation of those benefits. 


\section{g. Suspension}

Cheadle's assertion that there is evidence of wide scale abuse of suspension is borne out by a review of the case law and anecdotal evidence. This appears to be a phenomenon peculiar to the public sector where, as Cheadle notes, employees are arbitrarily suspended for months, if not years, pending an investigation into misconduct or a disciplinary enquiry. This appears to be a problem particularly apparent in the public section, where the cost of prolonged suspensions is borne at the cost of the taxpayer. For the above reasons, employer conduct in relation to suspension warrants review.

Cheadle is correct to suggest that suspension as a disciplinary penalty may be effected only with the employee's consent and that on this basis, it is only the use of suspension pending disciplinary action that requires review. Given the context in which employer conduct is to be regulated, extension of judicial scrutiny to suspension decisions to be provided for in Chapter VIII of the Act, in that part of the chapter dealing with unfair dismissal. The creation of a statutory obligation to conduct and conclude investigations into alleged misconduct within a reasonable time and the powers both to strike down the outcome of tardy disciplinary proceedings and to uplift unreasonably wrong periods of suspension ought to be established as remedies.

In summary:

- The continued application of the definition of unfair labour practice should be reviewed. The definition has been interpreted so as to allow matters of interest to be excluded from the ambit of the protection, and to confine its application to disputes of right. This axiomatically assumes there is adequate alternative protection against unfair conduct by employers, either in terms of a contract of employment or a statutory right.

- Of the elements that currently make up the definition of unfair labour practice, only suspension needs to be dealt with by statute, and legislative protection and judicial intervention should be built into those provisions of the Act regulating unfair dismissal.

- The repeal of the definition of unfair labour practice would immediately result in some 9000 less referrals to the CCMA (CCMA Annual Report) each year. 


\subsection{Collective Labour Law}

As Cheadle notes, the primary mechanism for achieving regulated flexibility was collective bargaining. One of the more controversial debates at the time the Labour Relations Act was drafted was whether the desirability of retaining a statutory duty to bargain. For the reasons set out in the Explanatory Memorandum that accompanied the Bill in 1995 (Cheadle 2006), the Act opts for a system of voluntary bargaining. It was specifically acknowledged that the ability of the economy to adapt to the changing requirements of a competitive global market was ensured only where employers and workers and their representatives were free to determine the nature and structure of bargaining institutions and the economic outcomes that bind them. At the same time, it was agreed that the voluntary nature of the system had to be underpinned by a set of organisational rights for unions, and for unions and employers, by the rights to strike and to lock out respectively.

The abolition of judicial interference in collective bargaining was not uncontroversial. The prophets of doom who at the time suggested that the levels of industrial conflict would increase exponentially as parties hammered out their differences through the exercise of economic power have been proved wrong. The Tokiso Report reflects a significant drop in industrial action since 1995, and that the majority of strikes have concerned wages rather than bargaining structures (Tokiso Report: 9-10). In fact, the Report's analysis of strike triggers between 1995 and 2004 does not even reflect duty to bargain issues as a strike trigger. What the Report does confirm is a shift in the pattern of collective bargaining, from plant level to more centralised fora, and a pattern of a significant lower number of industry strikes over wage issues (Tokiso Report: 10 ).

In short, the system of voluntary collective bargaining has worked, and leaving bargaining structures and related issues to the parties to resolve them has not resulted in any increase in industrial action. There appears to have been an incremented draft toward sectoral bargaining as the preferred level at which collective bargaining is conducted.

Employers fundamentally support the manner in which the Labour Relations Act regulates collective bargaining, and for the reasons recorded in the Explanatory Memorandum, would be opposed to any proposal to introduce a judicially enforceable duty to bargain. Self-governance remains a legitimate and the most desirable mechanism to establish terms and conditions of employment and to resolve disputes, within the framework of a voluntarist structure. 
However, employers have never supported and remain opposed to any policy that promotes sectoral level bargaining to any degree greater than that incorporated into the Labour Relations Act. In particular, employers remain of the view that any deepening or expansion of the coverage of bargaining councils is a matter for employers and organised labour in the sectors concerned, and that the state should have no role either in consolidating existing councils or promoting new ones.

Employers remain opposed to any system of sectoral bargaining that admits of two tier bargaining, and therefore do not support the model referred to in paragraph 116 of Cheadle's paper. Organised employers have never understood sectoral bargaining to imply necessarily that bargaining council agreements are only frameworks, and that supplementary bargaining would take place within these frameworks at the level of the enterprise.

Whether there is a bargaining council and the nature and content of a bargaining council agreement is for the parties to determine. Cheadle points out that the nature of bargaining council agreements has remained largely unchanged over the last 10 years. It is true that many agreements, particularly those concluded in the older bargaining councils, are highly detailed and cover the minutiae of working life within the sector. Again, that is the preference of the parties, and for employers, and particularly small employers, the advantages in terms of transactional costs remain compelling. If the nature and content of bargaining council agreements were to be prescribed and limited to broad minimum standards with the prospect of the obligation to negotiate more specific standards at plant level, employers would see few advantages to continued membership of employer organisations.

The most fundamental issue, from an employer perspective, is the problems created by bargaining councils for SMME's. The nature and extent of these has only recently been the subject of research. That research indicates that the key to the solution is for employer organisations to attract more small employers into membership. This would ensure greater representativity of employer organisations in those sectors that are covered by bargaining councils, or contemplating the establishment of a council (Godfrey, Maree \& Theron 2006). The data available to the researchers indicates that the council system primarily covers small business, and that for the system to survive, it has to become more representative of small business (Supra). This implies that employer organisations need to become more accommodating of small business and its needs. If any policy initiatives are to be developed, these are the issues that should be further canvassed. 
A further option identified by the research is the blanket exemption of particular categories of business, particularly small and new business, from bargaining council agreements. The 'phase in' approach contemplates a period within which start up businesses ought to work toward compliance with bargaining council agreements, and has apparently been adopted with some success by a number of bargaining councils ((Supra). The preferred alternative of the Presidential Commission to investigate labour market policy (June 1996) in regard to extensions of agreements was for agreements to establish a simple, less onerous schedule of minimum conditions for SMME's. This would acknowledge the unique circumstances of SSME's and the dualism in the labour market, but at the same time, keep all employers within a basic regulatory net. All of these findings and proposals has never been the subject of serious consideration. The basic research now available provides a useful platform for a tripartite discussion on accommodating SMME's within statutory bargaining structures

\section{a. Exemptions}

The research report into conditions of employment and small business suggests a number of policy options available to councils in respect of exemptions from collective agreements. All of these merit further consideration and in particular, the option of blanket exemptions for start up businesses in return for registration with the relevant council. The researchers' comment that there does not appear to be any sound justification for different councils to maintain separate criteria for the granting of exemptions also merits further discussion. In this regard, there is no reason why, contrary to what the researchers propose, consideration ought not to be given to maintaining specialised independent bodies to consider appeals against refusals of exemption. It may be appropriate to centralise the function, not under the auspices of the CCMA, but under a specialist tribunal whose members have particular knowledge of the small business environment.

\section{b. Basic Conditions of Employment Act}

The policy choice to recognise collective bargaining as the primary means of fixing terms and conditions of employment did not entirely find reflection in the Basic Conditions of Employment Act when that Act was negotiated. Variations to basic conditions through the mechanisms of collective bargaining are permissible in limited circumstances, and the sense is that collective bargaining was not entirely trusted as a means to introduce flexibility measures. 
The parties to collective bargaining arrangements in a sector are best placed to determine the nature and extent of any variations to Basic Conditions of Employment Act standards that apply in this sector. There is no reason to limit the flexibility, particularly of bargaining councils, to vary basic conditions except for those that constitute fundamental rights. This enhanced capacity of bargaining councils to vary basic conditions may also serve as an inducement to employees to join and form sectoral bargaining structures.

Finally, historical anomalies in the regulation of basic conditions of employment continue to exist. For example, Sunday work in the mining industry remains separately regulated by a piece of legislation that but for the limitation, has been repealed. These inconsistencies have limited flexibility arrangements in the sectors concerned.

\subsection{Labour Market Institutions}

\subsubsection{The Labour Courts}

Any discussion on the Labour Court most necessarily focus on the provisions of the Superior Courts Bill. The Bill proposes the integration of the Labour Appeal Court into the Supreme Court of Appeal, and of the Labour Court into the High Court.

Organised business and organised labour originally agreed to that proposal, subject to certain conditions, on the basis that the Department of Justice intended to abolish specialised courts, an intention that was reflected in a previous draft of the Bill.

The Bill placed before Parliament specifically contemplates specialist courts, inter alia, for competition, disputes, tax disputes, electoral disputes and land claims. All of these Courts are established as single courts with national jurisdiction. There is no cogent reason why Labour Courts, having enjoyed a degree of speciality since 1980, should not be retained as a specialist court. Employers support the integration of the Labour Appeal Court into the Supreme Court of Appeal, since the Constitution specifically contemplates the Supreme Court of Appeal as a final court of appeal in all but constitutional matters.

The appointment of judges through a specialist Labour Court with the status contemplated for judges of other specialist courts will resolve current problems with the status and terms of appointment of Labour Court judges. 
If the Labour Court is integrated into the High Court system as currently contemplated by the Superior Court's Bill, worker and employer rights will be significantly undermined. In particular, the obligation to litigate on a provincial rather than a national basis will compromise national unions and national employer organisations engaged in national disputes. Rights of representation will also be affected in the sense that the nature and structure of High Courts will not be conducive to the exercise of rights of appearance by trade union and employer organisation officials. Finally, the required degree of specialist knowledge, expertise and experience will continue to be available through the auspices of a specialist court - these will be lost if more generally appointed panels hear labour disputes.

In the light of the pending legislation, there is little point in pursuing a review of the efficiency of the Labour Court. Anecdotal evidence does suggest however that delays in finalising matters has become the norm, and that waiting periods of 12-18 months from referral to date of hearing, are common. In the Labour Appeal Court it is reported that delays of $12-18$ months between date of hearing and date of judgment are not uncommon. These issues should be further investigated once the Superior Courts Bill becomes law, and the opportunity arises to redraft the Labour Court rules.

\subsubsection{The CCMA}

The CCMA's primary functions are the conciliation and arbitration of disputes. The CCMA services 72 per cent of the employed population; the balance being served by bargaining councils (Tokiso Report : 17).

When the Labour Relations Act was implemented, the CCMA's caseload was estimated, for budgetary purposes, in the region of 36000 referrals. This figure was a gross underestimation. By 2000, the caseload was over 80000 referrals per annum. In 2005, more than 120000 disputes were referred to the CCMA. The number of referrals have risen each year, albeit at different rates. Between 1999/2000 and 2004/2005, the number of referrals grew by 47 per cent. Since the CCMA's budget has, in real terms, never been increased, the clear implication is that the CCMA has always been and remains hopelessly underfunded.

An integral component of the new dispute resolution structures introduced in 1995 was a trade-off between increased public expenditure on dispute resolution structures and benefits that were anticipated in the form of lower levels of industrial action. Despite its 
limited resources, the CCMA has contributed to a marked reduction in the number of strikes, with the consequent cost saving to the economy and the loss of the perception that South Africa economy is strike prone. The Tokiso Report concludes that the high proportions of strikes that are procedurally compliant are indicative that "the strike weapon is neither overzealously used, nor that the legislation and the dispute resolution mechanisms are not effective in maximising opportunity for dispute resolution, and doing so swiftly and effectively. This is in stark distinction to the institutional and legislative framework surrounding industrial action in the earlier stages of South African history." (Tokiso Report: 12).

The CCMA reports that approximately one third of referrals are rejected at the application stage (presumably for lack of jurisdiction or non-compliance) but as the Tokiso Report notes, it is not clear whether these disputes are referred again when initially rejected on technical grounds, or referred to other bodies (bargaining councils) that have the necessary jurisdiction (Tokiso Report: 22). The fact that one case in three has to be screened and rejected is indicative of high and unnecessary administrative costs being incurred, and reinforces the suggestion that these are the consequence of a limited understanding by employees of the nature and extent of their rights (Tokiso Report: 2324).

The CCMA consistently reports that around 80 per cent of all rights disputes referred concern unfair dismissal. The Tokiso Report suggests that the biggest referring industries are the unorganised sectors and/or less formal sectors, and that these account for some 58 per cent of referrals. The conclusion drawn is that since bargaining councils cover 'blue collar' workers, 40 per cent of referrals to the CCMA are made by 'white collar' workers from industries such as professional services, banking, parasols and the like (Tokiso Report: 32). The Report observes that this conclusion is contrary to the principle that the CCMA would be accessible to the indigent and the poor- it appears that a wealthier class of worker is the prime utilisers of the CCMA, and that self styled 'labour law advisers' who ply their trade primarily in this category contribute to the number of referrals. The figures reinforce the argument for excluding senior managers from the ambit of statutory work security rights.

The outcomes of referrals of rights disputes raises interesting questions. The Tokiso Report notes that in its analysis of a sample of 1750 awards, 60 per cent of cases favoured the employer, 4 per cent did not fall within the jurisdiction of the dispute resolution body, and 36 per cent of awards favoured the employee. In other words, two 
thirds of awards favour the employer party. This is indicative of the fact that it is the merits that generally dictate the outcome of a case, and that the widely held perception amongst employers that the CCMA is biased in favour of employees has no foundation.

The CCMA Rules make provision for the awarding of costs against unsuccessful parties. This provision is academic- costs are awarded in only 0.07 per cent of cases (Tokiso Report: 57). Attempts have been made on two occasions to address the rate of referrals and consequent cost to the CCMA by making an award for costs the more common consequence of referring a frivolous claim to the CCMA. Proposals were also made to provide for a 'filing fee' by prospective litigants in order to discourage frivolous referrals. On neither occasion was any substantial change conceded by organised labour, and the reality remains that there is little or no disincentive to using the CCMA to prosecute the most trivial and frivolous of claims.

This has had two serious consequences. The first is that the statutory dispute resolution structures, as is apparent from the CCMA's own reports and the research that has been done, are under strain. Ironically, by getting wrong the balance between the good of easy access to mechanisms of protection and the bad of abuse of the system, access to expeditious and efficient dispute resolution has been frustrated. Secondly, the "nothing to lose' scenario that now exists in the CCMA has encouraged the emergence of the unregulated consultants and other advisers of dubious repute who trade on the prospect of a 'nuisance value' settlement with employers to secure payment of their fees.

In the civil courts, parties generally embark on litigation after taking a considered view of their prospects of success, factoring the potential for an adverse cost order into the equation. There is no reason why the same principle should not apply in labour disputes.

Finally, the question of representation in CCMA and Labour Court proceedings requires urgent resolution, because those who can least afford it (dismissed workers and small employers) are the objects of scams that not only fuel perceptions about the nature of South African labour laws, they incur significant and unwarranted costs for the parties concerned. The Labour Relations Act sought to exclude legal representatives from most arbitration hearings. The rationale for this rule was explained in the Explanatory Memorandum to the draft Bill. Recognised categories of representatives included officials of registered trade unions and employer organisations, both as a measure to encourage recognition and to give effect to the rights of worker and employer representatives. These measures have been seriously undermined. Anecdotal evidence in the Tokiso Report 
(supported by the writer's personal experience) is that many of the employer and worker organisations that have sought and gained recognition in the last decade are fronts for consultancies, and are established for the primary purpose of representing clients before the CCMA and the Labour Court. These organisations will commonly demand a contingency file of 30-50 per cent of any settlement or award, and are not subject to the discipline of any professional body. 


\section{Conclusions}

In general terms, the conclusions recorded below reflect the argument that while South African labour law is not as inflexible as may be thought to be the case, many of the flexibilities that are inherent in the relevant international standards were never considered for incorporation into the appropriate legislation. There may have been valid historical reasons for this, and the assumption that all employees ought necessarily to enjoy the fullest possible set of labour rights. The variance between flexibility measures commonly recognised and applied internationally and existing South African legislation, and the consequent disjuncture between that legislation and common international practice and experience, has fuelled employer and investor views on the inflexibility of South African labour laws. This is particularly so in relation to work security rights.

A second strand of argument has suggested that many of the current misconceptions about South African labour law are the consequence of unintended consequences of the legislative package crafted during the 1990's. In particular, the unanticipated number of referrals of disputes to statutory dispute resolution structures has compromised their efficient operation. The lack of any disincentives to refer matters for conciliation and adjudication has led to a 'nothing to lose' culture, which has been fed by unregulated consultants and some legal practitioners. The same interests have presented and continue to present South African dismissal law as more complex than the principles established by the principal statute and the Codes of Good Practice. Clarity on the rules that apply, the education of commissioners and users of the CCMA, and the appropriate regulation of labour consultants and advisers will correct these misconceptions about South African labour law.

Where appropriate, the more specific conclusions presented below are followed by proposals, indicated in bold type.

1. The debate on regulating the labour market and small business cannot be divorced from a broader discussion on labour legislation and its impact on the cost of doing business in South Africa. Employer and investor perceptions on the rigidity of the South African labour market are not exclusively focussed on small business; they are primarily directed at what Cheadle describes as elements of labour market regulation in the first economy. Any measures that are adopted to address rigidities or perceptions of rigidities at that level will inevitably and obviously benefit small 
business.

2. The model underpinning South African labour legislation is basically sound, and no fundamental rethink of labour legislation is necessary. Existing inflexibilities and employer and investor perceptions of labour market rigidity in South Africa can be addressed by a number of amendments that would recognise and implement the flexible nature of international standards, and more closely align South African labour law with international practice.

3. Limitations of labour law rights and differences in treatment for small business are recognised by international labour standards and international practice. A separate legal regime for small business or a total exemption from the existing regime is not an appropriate option, given South Africa's international obligations and domestic constitutional constraints. What is required is an evaluation of existing forms of regulation and an assessment of the appropriateness of the nature and extent of that regulation, given the exigencies of SMME's and their capacity for creating employment. To the extent that small business is recognised as a discrete category warranting exclusion (as has been suggested in relation to unfair dismissal) a definition of small business may be necessary. The most pragmatic approach is to limit the application of laws, as most other jurisdictions have done, by reference to the number of employees engaged in the enterprise.

4. At the level of individual labour law, a greater degree of flexibility is afforded by international standards than might be thought to exist. In particular, ILO Conventions regulating security of employment specifically contemplate the exclusion of workers serving a qualifying period of employment from certain forms of protection. It is only an excessively long period qualifying period that will result in the denial of the protection laid down in the Convention.

\section{Chapter VIII of the Labour Relations Act should be amended to introduce a qualifying period. International practice suggests that a period of 6-12 months is the norm.}

5. ILO Convention 158 also contemplates the prospect of the exclusion from unfair dismissal laws of workers by reference to the size of the undertaking that employs them. International experience suggests that it is common for dismissal laws to be 
excluded from application to enterprises employing less than a specified number of workers. These measures are intended to permit small enterprises a greater degree of latitude and flexibility in responding to demand and a greater recognition of the more limited ability of small enterprises to bear the administrative and economic costs of associated with unfair dismissal laws.

\begin{abstract}
A threshold should be imposed, by reference to the number of employees engaged by an employer, below which workers engaged in the enterprise have no protection against unfair dismissal.
\end{abstract}

6. International labour standards do not require a formal hearing prior to dismissal. South African law contemplates minimal requirements in terms of workplace procedures, with a right to challenge dismissal decisions, on the merits, in an arbitration hearing. The interpretation of South African labour legislation as requiring formal, adversarial and court like hearings before effecting a dismissal is one of the factors most responsible for the high cost in terms of hours expended and monies invested in exercising workplace discipline. This dislocation between policy (as expressed in the Code of Good Practice) and practice is difficult to explain, but the vested interests of consultants and other advisers is a major factor.

The Labour Relations Act should be amended to clearly and unambiguously spell out the requirements of fair procedure. These requirements should be limited to an opportunity to state a case in response to employer allegations of misconduct and incapacity, without the need for a formal hearing.

7. In the case of retrenchments, international labour standards and international practice recognise the desirability and legitimacy of excluding small business from the ambit of consultation and information obligations.

Employers employing less than a defined number of workers (20 seems to be an international norm) should be exempted from the requirements of section 189 of the Labour Relations Act. In any event, sections 189 and 189A should be collapsed into a single, less complex provision more clearly establishing the nature and extent of substantive and procedural fairness and the disputes procedures available to disaffected parties. 
8. The concept of the unfair labour practice is one that has its roots in controversy. There is no basis for legislative protection against unfair labour practices as currently defined. Legislative protection and judicial intervention should be limited to breaches of fundamental rights and breaches of collective and individual agreements regulating employer conduct. Suspension as part of the disciplinary process should be regulated as an integral part of unfair dismissal laws.

The definition of unfair labour practice should be reviewed, and those elements of the definition that are regulated by common-law contractual rules or other statutory remedies should be deleted from the definition. Statutory protection against the abuse of suspension should be retained.

9. At the level of collective labour law, the basis on which collective bargaining is regulated through the Labour Relations Act remains sound. Bargaining council agreements that meet the existing requirements for extension should be subject to a revised exemption procedure.

10. There is no imperative to strengthen and deepen sector level bargaining. The reality in many sectors is that unions and employer organisations are not sufficiently representative for sectoral level bargaining structures to be established. The artificial segmentation of the economy into sectors and a policy that recognises sectoral level bargaining as the norm is misconceived.

11. The Basic Conditions of Employment Act should afford greater capacity to vary standards through collective bargaining. An increased capacity to vary basic conditions of employment through sectoral structures would be a major incentive to the establishment of bargaining councils.

12. The labour market institutions established by the Labour Relations Act have enjoyed varied levels of efficiency since 1994. The CCMA continues to discharge its statutory obligations under difficult circumstances and financial constraints. Current attempts to improve efficiencies should be continued and extended, and sufficient allocation of funding should be ensured to enable the CCMA to discharge its statutory obligations. 
13. One of the primary problems is unrestricted access to the CCMA remains unrestricted, and the absence of any checks in the system to filter out cases with no merit and disincentives to workers who file frivolous claims. This more than any other factor has spawned the 'try your luck' culture that characterises CCMA proceedings. There should be financial risk to both parties to unfair dismissal proceedings.

The CCMA Rules should make costs orders the norm rather than the exception, and to require the payment of a filing fee or the furnishing of security for costs in appropriate cases.

14. Rights to representation before the Labour Courts and the CCMA should be reviewed. At present, the system extends rights of representation to persons who are not subject to the regulation of any professional body. The failure by the CCMA's governing body to agree on proper regulatory measures has resulted in wide scale abuse, to the detriment of those who can least afford it.

The proposals to regulate representation before the CCMA formulated during the 2002 amendment process should be revisited.

15. The enactment of the Superior Courts Bill in its present form will undermine the structures agreed by organised business and labour, and result in greater degrees of inefficiency and cost. SMME's will be particularly prejudiced, since labour disputes will inevitably become even more formalised in a High Court environment.

The Labour Court should be retained as a separate court, with the status of a Division of the High Court, and with national jurisdiction. The Rules of the Labour Courts should be reviewed in order to identify ways and means to expedite the adjudication of labour disputes. 


\section{References}

Baskin 'Jobs, Growth and Equity in a global Context' Paper delivered at the 11th Annual Labour Law Conference 1998.

CCMA Annual Report 2004/2005

Cheadle, $\mathrm{H}$. 'Regulating Flexibility: Revsiting the LRA and BCEA' (DPRU Working Paper 06/109)

Doing Business in 2006-Creating Jobs' World Bank 2006

Flanagan, "Labour Standards and International Competitive Advantage". In: International Labour Standards (Stanford) 2003. Flanagan, and Gould, (eds.)

Godfrey, Maree and Theron "Conditions of Employment and Small Business: Coverage, Compliance and Exemptions. Labour and Enterprise Project, University of Cape Town.

Hepple 'Labour Laws and Global Trade” Hart Publishing Oxford and Oregon 2005

Lee, 'Labour Market Regulation and Economic Growth' Paper presented to 11th Annual Labour Law Conference 1998

Louw, L. 'The Right to Work and the increasing demand for Labour" Free Market Foundation Feature Article August 2005. “Labour Laws Hinder Employment' The Star 29 August 2005.

Report on Dispute Resolution in South Africa 2005 Tokisos Johannesburg 2005.

Van Niekerk, A. 'In Search of Justification: The Origins of Statutory Protetcion of Security of Employmemnt in Souh Africa ' (2004) 25 ILJ 853

www.workchoices.gov.au. 